\title{
Channel Gains and Losses in the Opequon Creek Watershed of West Virginia, July 25-28, 2005
}

By Ronald D. Evaldi and Katherine S. Paybins

Prepared in cooperation with Berkeley County Commission

Data Series 179 


\section{U.S. Department of the Interior \\ Gale A. Norton, Secretary \\ U.S. Geological Survey \\ P. Patrick Leahy, Acting Director}

U.S. Geological Survey, Reston, Virginia: 2006

For product and ordering information:

World Wide Web: http://www.usgs.gov/pubprod

Telephone: 1-888-ASK-USGS

For more information on the USGS--the Federal source for science about the Earth, its natural and living resources, natural hazards, and the environment:

World Wide Web: http://www.usgs.gov

Telephone: 1-888-ASK-USGS

Any use of trade, product, or firm names is for descriptive purposes only and does not imply endorsement by the U.S. Government.

Although this report is in the public domain, permission must be secured from the individual copyright owners to reproduce any copyrighted materials contained within this report.

Suggested citation:

Evaldi, R.D., and Paybins, K.S., 2006, Channel gains and losses in the Opequon Creek Watershed of West Virginia, July 25-28, 2005: U.S. Geological Survey Data Series 179, 7 p. 


\section{Contents}

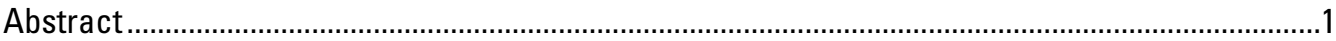

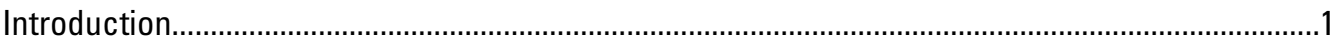

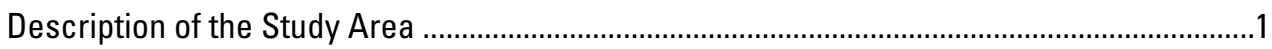

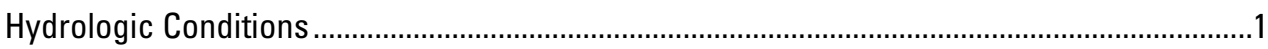

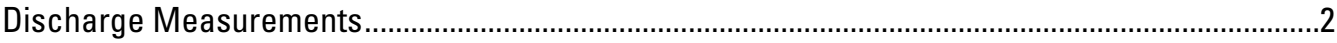

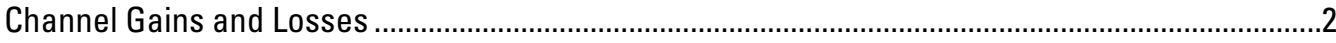

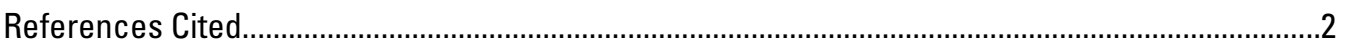

\section{Figure}

1. Map showing Channel gains and losses in the Opequon Creek watershed of West Virginia, July 25-28, 2005.. separate file

\section{Table}

1. Discharge measurements in the Opequon Creek watershed of West Virginia, July 25-28, 2005.

\section{Conversion Factors and Datums}

\begin{tabular}{|c|c|c|}
\hline Multiply & By & To obtain \\
\hline \multicolumn{3}{|c|}{ Length } \\
\hline inch (in.) & 2.54 & centimeter $(\mathrm{cm})$ \\
\hline foot $(\mathrm{ft})$ & 0.3048 & meter $(\mathrm{m})$ \\
\hline mile (mi) & 1.609 & kilometer $(\mathrm{km})$ \\
\hline \multicolumn{3}{|c|}{ Area } \\
\hline acre & 0.4047 & square hectometer $\left(\mathrm{hm}^{2}\right)$ \\
\hline square mile $\left(\mathrm{mi}^{2}\right)$ & 259.0 & square hectometer $\left(\mathrm{hm}^{2}\right)$ \\
\hline \multicolumn{3}{|c|}{ Flow rate } \\
\hline cubic foot per second $\left(\mathrm{ft}^{3} / \mathrm{s}\right)$ & 0.02832 & cubic meter per second $\left(\mathrm{m}^{3} / \mathrm{s}\right)$ \\
\hline gallon per minute (gal/min) & 0.06309 & liter per second $(\mathrm{L} / \mathrm{s})$ \\
\hline gallon per day (gal/d) & 0.003785 & cubic meter per day $\left(\mathrm{m}^{3} / \mathrm{d}\right)$ \\
\hline $\begin{array}{l}\text { gallon per day per acre } \\
{[(\text { gal/d)/acre }]}\end{array}$ & 0.000935 & $\begin{array}{l}\text { cubic meter per day per square } \\
\text { hectometer }\left[\left(\mathrm{m}^{3} / \mathrm{d}\right) / \mathrm{hm}^{2}\right]\end{array}$ \\
\hline
\end{tabular}

Horizontal coordinate information is referenced to the North American Datum of 1983 (NAD 83).

Vertical control information is referenced to the National Geodetic Vertical Datum of 1929 (NGVD 29).

Altitude, as used in this report, refers to distance above the vertical datum.

Temperature in degrees Fahrenheit $\left({ }^{\circ} \mathrm{F}\right)$ may be converted to degrees Celsius $\left({ }^{\circ} \mathrm{C}\right)$ as follows:

$$
{ }^{\circ} \mathrm{C}=\left({ }^{\circ} \mathrm{F}-32\right) / 1.8
$$




\title{
Channel Gains and Losses in the Opequon Creek Watershed of West Virginia, July 25-28, 2005
}

\author{
By Ronald D. Evaldi and Katherine S. Paybins
}

\begin{abstract}
Discharge measurements were made during July 25-28, 2005 , in streams and springs and at a wastewater-treatmentplant outfall in the Opequon Creek watershed of West Virginia to describe surface-water resources during low-flow. The greatest spring discharge measured was 6,460 gallons per minute, but 11 of 31 springs inspected were not flowing. Stream discharge measurements obtained at 69 sites defined gaining (influent) and losing (effluent) channel reaches. Drainage areas were determined for the channel measurement sites, and gains and losses of flow along the channels were expressed in terms of flow per unit drainage area to the reach. The greatest gain measured for a channel reach was approximately 11,100 gallons per day per acre, and the greatest loss was approximately 8,420 gallons per day per acre.
\end{abstract}

\section{Introduction}

Discharges of streams, springs, and a wastewater treatment plant outfall in the Opequon Creek watershed (fig. 1) in Berkeley and Jefferson Counties, W. Va., were measured during July 25-28, 2005. These measurements help describe surface-water resources during low-flow and provide data for calibration of a ground-water flow model being developed for the Opequon Creek watershed. Presentation of these measurements herein is the result of a cooperative effort with the Berkeley County Commission.

\section{Description of the Study Area}

The stream, spring, and outfall measurements described in this report were all made in the Opequon Creek watershed. Opequon Creek forms part of the boundary between Berkeley and Jefferson Counties in West Virginia and flows into the Potomac River northeast of Martinsburg (fig. 1). The Opequon Creek watershed is in the Great Valley, with gently rolling topography that ranges from about 310 to $800 \mathrm{ft}$ in altitude. The watershed has a trellis drainage pattern; Opequon Creek flows generally parallel to bedrock strike, and its major tribu- taries flow across the strike. The area is underlain by limestone and some shale (Shultz and others, 1993). Faults (fig. 1) collect water along their length from tributary faults, fractures, and solution channels and serve as pathways for downgradient flow to points of discharge (Hobba and others, 1972).

The Opequon Creek watershed is an area of rapid population growth. The 2004 populations of Berkeley County $(89,400)$ and of Jefferson County $(47,700)$ were about 50 and 33 percent larger, respectively, than those in 1990 (U.S. Census Bureau, 2006). The West Virginia Division of Water and Waste Management did an ecological assessment of West Virginia streams draining directly to the Potomac River during 1998. They reported that most of Berkeley, Jefferson, and Morgan Counties were covered by forests except for the Opequon Creek watershed. They reported that drainage basins for 10 of the 15 sites that they sampled in the Opequon Creek watershed had less than 50 percent areal coverage by forests and that 3 basins had the greatest percentage of urban coverage of all sites sampled in the 3-county area (West Virginia Division of Water and Waste Management, 2005). They reported further that agriculture was the major land use in the Opequon Creek watershed during their 1998 study and that new residential construction and other developments were rapidly converting both forest and farmland into more urban environments.

\section{Hydrologic Conditions}

Streamflow at USGS gaging station 01616500 Opequon Creek near Martinsburg (site 39, table 1, fig. 1) averaged $106 \mathrm{ft}^{3} / \mathrm{s}(47,600 \mathrm{gal} / \mathrm{min})$ during July $25-28$, which was approximately equivalent to the 40 percent flow duration (flow equaled or exceeded 40 percent of the time) of summer flows reported by Wiley (2006). The station recorded a hydrograph rise to $210 \mathrm{ft}^{3} / \mathrm{s}(94,300 \mathrm{gal} / \mathrm{min})$ on July 22 , but this flow reflects runoff from the entire $273-\mathrm{mi}^{2}$ upstream drainage area and probably did not include any significant storm runoff from the study area; rainfall totaled only 0.02 in. during July 16-24 at Martinsburg (National Climatic Data center, 2005). Flows of the streams and springs measured during the study were assumed to be principally from ground-water discharge rather than from surface runoff, even though 0.12 in. of rain fell in 
Martinsburg on July 25 and 0.13 in. fell July 27. Most rain was believed to have been evapotranspired as a result of high temperatures (62 to $97{ }^{\circ} \mathrm{F}$ ) during July 25-28 in the Martinsburg area (National Climatic Data Center, 2005), except for some direct street runoff in the most urban sections of the watershed.

The long-term ground-water recharge of the Opequon Creek watershed upstream from the gaging station was estimated by Kozar and Mathes (2001) as 9.8 in./yr or, in terms of average annual streamflow, $197 \mathrm{ft}^{3} / \mathrm{s}(88,400 \mathrm{gal} / \mathrm{min})$; thus, the flow of Opequon Creek was about 54 percent of the average annual ground-water recharge rate. A discharge measurement of $4.7 \mathrm{ft}^{3} / \mathrm{s}(2,100 \mathrm{gal} / \mathrm{min})$ was made at the site of the discontinued USGS gaging station 01617000 Tuscarora Creek above Martinsburg (site 52; table 1, fig. 1). Kozar and Mathes (2001) estimated ground-water recharge of the Tuscarora Creek watershed upstream from the Tuscarora Creek station as $11.4 \mathrm{in} . / \mathrm{yr}$ or, in terms of average annual outflow, $9.5 \mathrm{ft}^{3} / \mathrm{s}$ (4,260 gal/min); thus, the flow of Tuscarora Creek was about 49 percent of the average annual ground-water recharge rate.

\section{Discharge Measurements}

Discharge information was obtained during July 25-28, 2005, at 69 stream sites, 31 springs, and 1 wastewater-treatment-plant outfall in the Opequon Creek watershed of West Virginia (table 1, fig. 1). Some springs and stream channels were found to be dry. All flowing sites were measured by wading with current meters. Observations of width, depth, and velocity were made at intervals in a cross section of the stream or spring outflow. Measured discharge is the summation of the products of the subsection areas of the cross sections and their respective average velocities (Rantz and others, 1982). Equipment used for measuring flow was checked for accuracy before and after the study and was within acceptable operational limits. The accuracy of individual discharge measurements was dependent on channel or outflow conditions, and error generally was estimated to be less than 10 percent.

Streamflow diversions and evaporation affect the results of this study. Pumps were noted as running during the time of the outflow measurements at Kilmer Spring and at Lefevre Spring, but data were not adjusted because the amount of diversion was unknown. Other unknown diversions or unnatural inflows could have occurred during the study. The rate of evapotranspiration from the streams during the study was also unknown and was thus considered as channel loss.

The greatest measured spring discharge was $14.4 \mathrm{ft}^{3} / \mathrm{s}$ $(6,460 \mathrm{gal} / \mathrm{min})$ from Priest Field Spring (site S1; table 1, fig. 1), but 11 of 31 springs were found to be not flowing. Streamflow measurements were made at 60 sites, and no flow was observed at 9 locations (table 1). The greatest tributary streamflow to Opequon Creek was from Tuscarora Creek, which measured $17.0 \mathrm{ft}^{3} / \mathrm{s}(7,630 \mathrm{gal} / \mathrm{min})$ at Burke Street (site 65 ; table 1, fig. 1 ).

\section{Channel Gains and Losses}

Channels in carbonate terrane can lose flow along some reaches through solution openings in the streambed when the stream channel is above the ground-water level. This water can return to a channel by springs and seeps downstream, or possibly in an adjacent watershed where the ground-water level is above the stream channel. Through this process, various reaches of a stream channel can lose or gain water. A stream can be deficient in flow or completely dry if the groundwater level is below the stream channel and solution openings beneath the stream are extensive enough to divert streamflow underground, thus draining the area by subsurface routes. Gains or losses of flow along channels can be attributed to one or more of the following: evapotranspiration, unmeasured tributary inflow, surface-water diversions, subsurface flow in unconsolidated channel deposits, interaction with the groundwater system, flow to or from faults, or measurement error.

Opequon Creek was measured at three locations (sites 15, 39, and 66; table 1, fig. 1), and showed a gain of $8 \mathrm{ft}^{3} / \mathrm{s}$ $(5,200,000 \mathrm{gal} / \mathrm{d}$ ) from river miles 26 (site 15$)$ to 11.6 (site $39)$ and a further gain of $32 \mathrm{ft}^{3} / \mathrm{s}(20,700,000 \mathrm{gal} / \mathrm{d})$ to river mile 3.3 (site 66). This gain can also be expressed in flow per unit of intervening drainage area between the sites as a gain of about 116 (gal/d)/acre between Opequon Creek river miles 26.0 to 11.6 and a gain of about $567(\mathrm{gal} / \mathrm{d}) /$ acre between river miles 11.6 and 3.3.

The tributaries to Opequon Creek were measured at 66 locations during July 25-28, 2005. Drainage areas were determined for the channel-measurement sites, and the gains and losses of flow along the channel were expressed in terms of flow per unit drainage area contributing to the reach (table 1, fig. 1). The greatest measured gain for a channel reach was $11,100(\mathrm{gal} / \mathrm{d}) /$ acre between sites 42 and 43 on Evans Run, but flow in this channel reach may have been affected by leaking water lines, which were observed upstream from site 43 . The greatest gain for a channel reach with no known artificial inflow was 5,110 (gal/d)/acre upstream from site 37, which includes a wetland area. The greatest loss measured for a channel reach was $8,420(\mathrm{gal} / \mathrm{d}) /$ acre between sites 43 and 44 on Evans Run, which is immediately downstream from the greatest gaining reach measured during the study.

\section{References Cited}

Hobba, W.A., Friel, E.A., and Chisholm, J.L., 1972, Water resources of the Potomac River basin, West Virginia: West Virginia Geological Survey River Bulletin 3, 110 p.

Kozar, M.D., and Mathes, M.V., 2001, Aquifer-characteristics data for West Virginia: U.S. Geological Survey WaterResources Investigations Report 01-4036, 74 p. 
National Climatic Data Center, 2005, Unedited local climatological data, accessed January 17, 2006, at http://cdo.ncdc. noaa.gov/ulcd/ULCD

Rantz, S.E., and others, 1982, Measurement and computation of streamflow-Volume 1, Measurement of stage and discharge: U.S. Geological Survey Water-Supply Paper 2175, p. $79-183$.

Shultz, R.A., Hobba, W.A., and Kozar, M.D., 1993, Geohydrology, ground-water availability, and ground-water quality of Berkeley County, West Virginia, with emphasis on the carbonate rock area: U.S. Geological Survey WaterResources Investigations Report 93-4073, 88 p.

U.S. Census Bureau, 2006, State \& county QuickFacts, accessed January 13, 2006, at http://quickfacts.census. gov/qfd/states

West Virginia Division of Water and Waste Management, 2005, Ecological assessments of West Virginia's watersheds: West Virginia Department of Environmental Protection Report number 02070004, accessed January 13, 2006, at http://www.dep.state.wv.us/Item. cfm? ssid $=11 \& S S 1 I D=718$

Wiley, J.B., 2006, Low-flow analysis and selected flow statistics representative of 1930-2002 for streamflow-gaging stations in or near West Virginia: U.S. Geological Survey Scientific Investigations Report 2006-5002, 190 p. 
Table 1. Discharge measurements in the Opequon Creek Watershed of West Virginia, July 25-28, 2005.

[ft ${ }^{3} / \mathrm{s}$, cubic feet per second; gal/min, gallon per minute; gal $/ \mathrm{d}$, gallon per day]

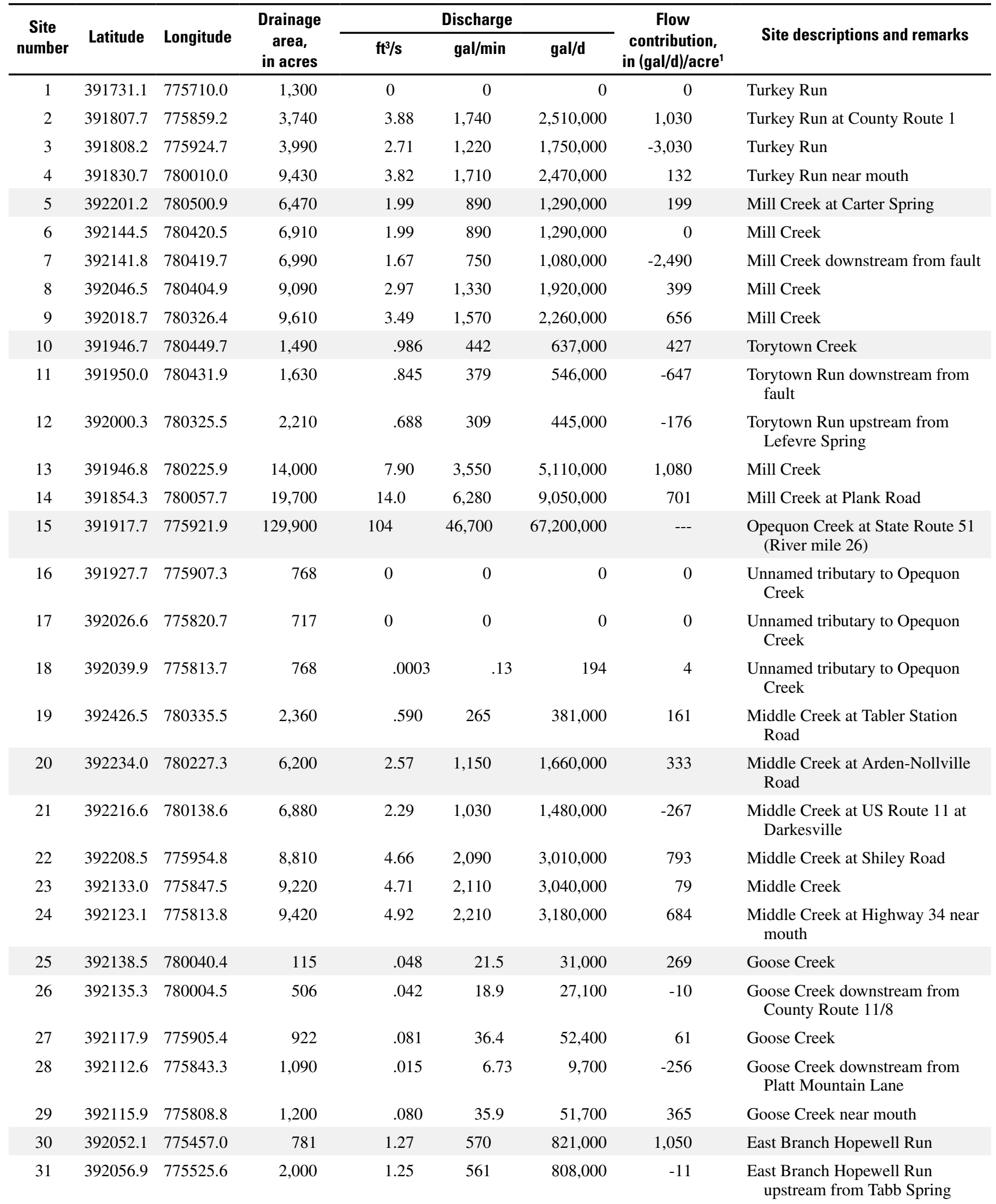


Table 1. Discharge measurements in the Opequon Creek Watershed of West Virginia, July 25-28, 2005.-Continued

[ft $\mathrm{ft}^{3} / \mathrm{s}$, cubic feet per second; gal/min, gallon per minute; gal/d, gallon per day]

\begin{tabular}{|c|c|c|c|c|c|c|c|c|}
\hline \multirow{2}{*}{$\begin{array}{c}\text { Site } \\
\text { number }\end{array}$} & \multirow{2}{*}{ Latitude } & \multirow{2}{*}{ Longitude } & \multirow{2}{*}{$\begin{array}{c}\text { Drainage } \\
\text { area, } \\
\text { in acres }\end{array}$} & \multicolumn{3}{|c|}{ Discharge } & \multirow{2}{*}{$\begin{array}{c}\text { Flow } \\
\text { contribution, } \\
\text { in (gal/d)/acre }{ }^{1}\end{array}$} & \multirow{2}{*}{ Site descriptions and remarks } \\
\hline & & & & $\mathrm{ft}^{3} / \mathrm{s}$ & $\mathrm{gal} / \mathrm{min}$ & $\mathrm{gal} / \mathrm{d}$ & & \\
\hline 32 & 392038.7 & 775607.2 & 3,060 & .062 & 27.8 & 40,100 & 13 & South Branch Hopewell Run \\
\hline 33 & 392116.7 & 775601.0 & 5,570 & 4.12 & 1,850 & $2,660,000$ & 3,500 & Hopewell Run at Leetown \\
\hline 34 & 392219.5 & 775625.0 & 7,020 & 5.56 & 2,500 & $3,590,000$ & 643 & Hopewell Run near mouth \\
\hline 37 & 392344.3 & 775518.0 & 4,520 & 2.69 & 1,210 & $1,740,000$ & 5,110 & $\begin{array}{l}\text { Shaw Run downstream from Shaw } \\
\text { Spring wetland }\end{array}$ \\
\hline 38 & 392416.4 & 775547.1 & 4,930 & 3.32 & 1,490 & $2,150,000$ & 979 & Shaw Run near mouth \\
\hline 41 & 392555.5 & 780101.7 & 1,470 & 0 & 0 & 0 & -26 & Evans Run at State Route 45 \\
\hline 42 & 392535.7 & 775915.6 & 3,400 & 0 & 0 & 0 & 0 & Evans Run at US Highway 11 \\
\hline 43 & 392530.3 & 775851.5 & 3,650 & 4.29 & 1,930 & $2,770,000$ & 11,100 & $\begin{array}{l}\text { Evans Run below ford (leaking } \\
\text { water lines upstream) }\end{array}$ \\
\hline 44 & 392533.4 & 775842.7 & 3,670 & 4.04 & 1,810 & $2,610,000$ & $-8,420$ & $\begin{array}{l}\text { Evans Run about } 0.5 \text { mile down- } \\
\text { stream from Big Spring }\end{array}$ \\
\hline 45 & 392528.8 & 775629.3 & 4,570 & 2.94 & 1,320 & $1,900,000$ & -788 & Evans Run near mouth \\
\hline 46 & 392704.4 & 780243.8 & 1,750 & .433 & 194 & 280,000 & 160 & Tuscarora Creek \\
\hline 47 & 392730.4 & 780245.0 & 250 & .065 & 29.2 & 42,000 & 168 & $\begin{array}{l}\text { Unnamed spring tributary to } \\
\text { Tuscarora Creek }\end{array}$ \\
\hline 51 & 392811.0 & 775846.7 & 7,190 & 4.69 & 2,110 & $3,030,000$ & 1,350 & $\begin{array}{l}\text { Tuscarora Creek at North } \\
\text { Tennessee Ave }\end{array}$ \\
\hline 52 & 392811.3 & 775819.6 & 7,430 & 4.68 & 2,100 & $3,020,000$ & -27 & $\begin{array}{l}\text { Tuscarora Creek above Martins- } \\
\text { burg }\end{array}$ \\
\hline 53 & 392801.9 & 775808.2 & 7,600 & 4.84 & 2,170 & $3,130,000$ & 598 & Tuscarora Creek \\
\hline 54 & 392944.7 & 780038.7 & 851 & .454 & 204 & 293,000 & 345 & $\begin{array}{l}\text { Dry Run downstream from } \\
\text { County Route } 13\end{array}$ \\
\hline 55 & 392934.8 & 775958.5 & 1,290 & .424 & 190 & 274,000 & -45 & $\begin{array}{l}\text { Dry Run at Apple Knolls } \\
\text { subdivision }\end{array}$ \\
\hline 56 & 392907.7 & 775915.8 & 1,850 & .137 & 61.5 & 88,500 & -329 & $\begin{array}{l}\text { Dry Run upstream of Southern } \\
\text { tributary }\end{array}$ \\
\hline 57 & 392904.3 & 780102.1 & 531 & 0 & 0 & 0 & 0 & $\begin{array}{l}\text { Southern tributary to Dry Run at } \\
\text { County Route } 16\end{array}$ \\
\hline 58 & 392903.4 & 775958.6 & 909 & 0 & 0 & 0 & 0 & $\begin{array}{l}\text { Southern tributary to Dry Run at } \\
\text { County Route } 13 / 1\end{array}$ \\
\hline 59 & 392902.9 & 775822.7 & 3,560 & .190 & 85.3 & 123,000 & 42 & Dry Run dounstream from I-81 \\
\hline
\end{tabular}


Table 1. Discharge measurements in the Opequon Creek Watershed of West Virginia, July 25-28, 2005.—Continued [ft $\mathrm{t}^{3} / \mathrm{s}$, cubic feet per second; gal $/ \mathrm{min}$, gallon per minute; gal/d, gallon per day]

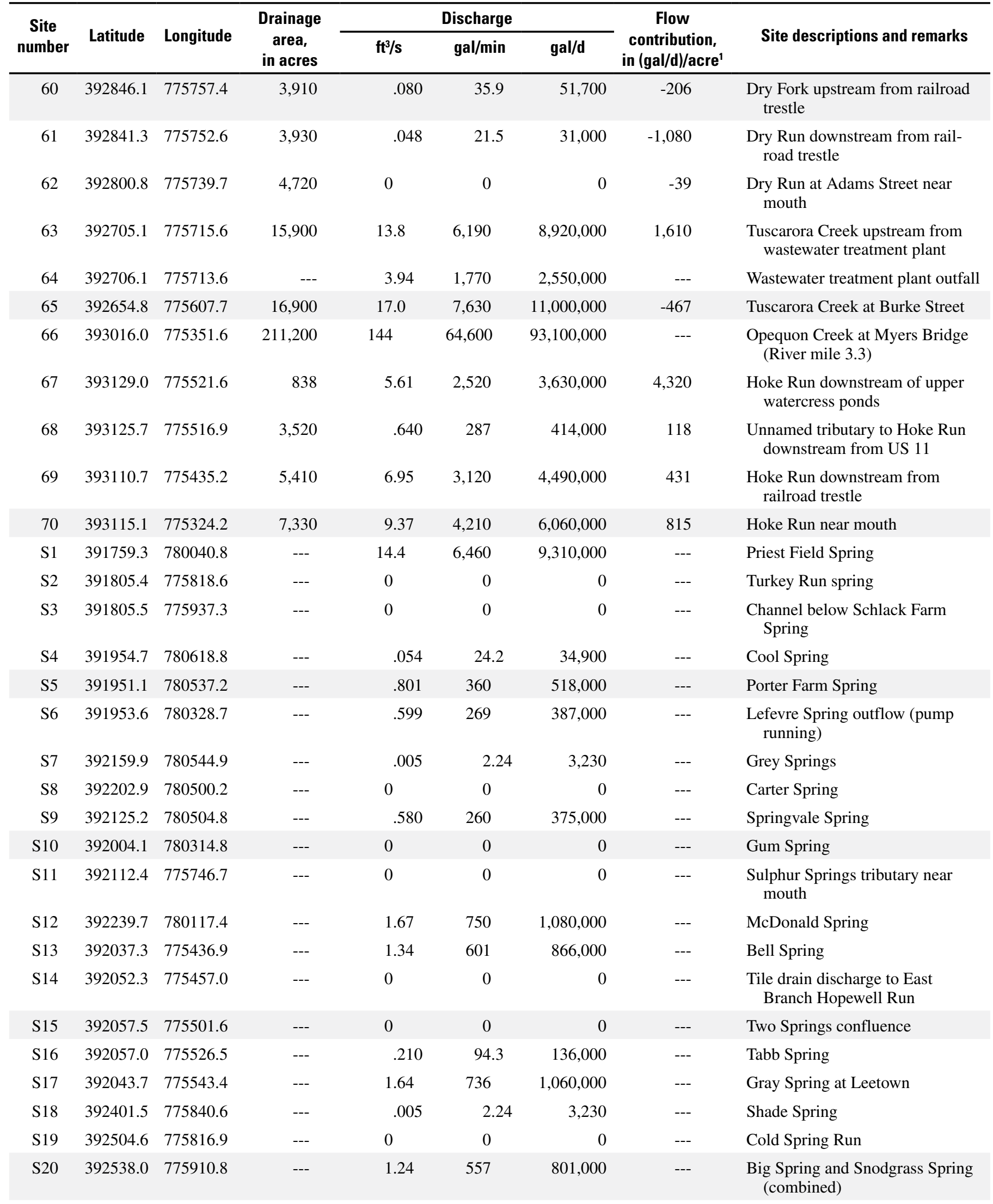


Table 1. Discharge measurements in the Opequon Creek Watershed of West Virginia, July 25-28, 2005.—Continued

[ft $3 / \mathrm{s}$, cubic feet per second; gal/min, gallon per minute; gal/d, gallon per day]

\begin{tabular}{|c|c|c|c|c|c|c|c|c|}
\hline \multirow{2}{*}{$\begin{array}{c}\text { Site } \\
\text { number }\end{array}$} & \multirow[b]{2}{*}{ Latitude } & \multirow[b]{2}{*}{ Longitude } & \multirow{2}{*}{$\begin{array}{l}\text { Drainage } \\
\text { area, } \\
\text { in acres }\end{array}$} & \multicolumn{3}{|c|}{ Discharge } & \multirow{2}{*}{$\begin{array}{c}\text { Flow } \\
\text { contribution, } \\
\text { in (gal/d)/acre }{ }^{1}\end{array}$} & \multirow[b]{2}{*}{ Site descriptions and remarks } \\
\hline & & & & $\mathrm{ft}^{3} / \mathrm{s}$ & gal/min & $\mathrm{gal} / \mathrm{d}$ & & \\
\hline S21 & 392803.2 & 780130.0 & --- & .700 & 314 & 452,000 & --- & BellaVista Distillery Spring \\
\hline $\mathrm{S} 22$ & 392758.8 & 775759.6 & --- & .426 & 191 & 275,000 & --- & Kilmer Spring overflow \\
\hline $\mathrm{S} 23$ & 392710.4 & 775745.0 & --- & .879 & 395 & 568,000 & --- & Martinsburg water supply spring \\
\hline S26 & 392653.8 & 775526.9 & --- & .703 & 316 & 454,000 & --- & Blarton Spring \\
\hline S27 & 392813.0 & 775237.3 & --- & .504 & 226 & 326,000 & --- & Swan Pond Spring \\
\hline $\mathrm{S} 28$ & 393126.8 & 775542.2 & --- & 5.83 & 2,620 & $3,770,000$ & --- & $\begin{array}{l}\text { Dennis Farm Spring upstream } \\
\text { from upper watercress pond }\end{array}$ \\
\hline $\mathrm{S} 31$ & 393108.0 & 775345.6 & --- & .175 & 78.5 & 113,000 & --- & $\begin{array}{l}\text { Spring on downstream side of } \\
\text { tributary to Hoke Run }\end{array}$ \\
\hline
\end{tabular}

${ }^{1}$ Flow contributions are computed as the change in channel discharge between measurement sites divided by the change in drainage area between the sites. Contributions are negative for losing (effluent) reaches and positive for gaining (influent) reaches. See figure 1 for areas associated with the flow-contribution calculations for the indicated measurement sites. 